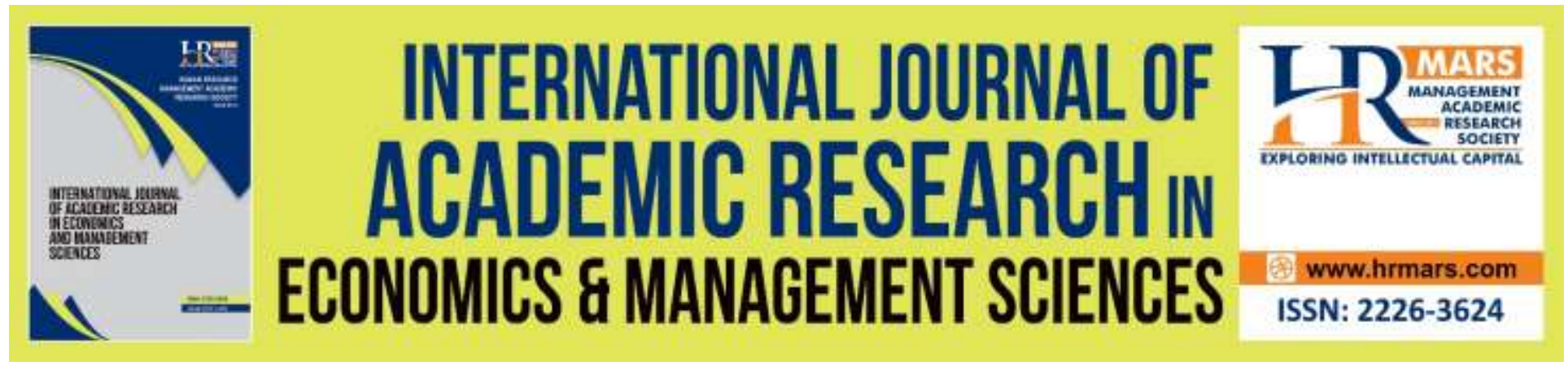

\title{
Human Capital Investment in Bangladesh: Issues and Options
}

Muhammad Helal Uddin, Sisheng Xie

To Link this Article: http://dx.doi.org/10.6007/IJAREMS/v8-i3/6451

DOI: $10.6007 /$ IJAREMS/v8-i3/6451

Received: 13 August 2019, Revised: 09 Sept 2019, Accepted: 21 Sept 2019

Published Online: 17 Oct 2019

In-Text Citation: (Uddin \& Xie, 2019)

To Cite this Article: Uddin, M. H., \& Xie, S. (2019). Human Capital Investment in Bangladesh: Issues and Options. International Journal of Academic Research in Economics and Management Sciences, 8(3), 12-29.

Copyright: (C) 2019 The Author(s)

Published by Human Resource Management Academic Research Society (www.hrmars.com)

This article is published under the Creative Commons Attribution (CC BY 4.0) license. Anyone may reproduce, distribute, translate and create derivative works of this article (for both commercial and non-commercial purposes), subject to full attribution to the original publication and authors. The full terms of this license may be seen at: http://creativecommons.org/licences/by/4.0/legalcode

Vol. 8, No. 3, 2019, Pg. 12 - 29

http://hrmars.com/index.php/pages/detail/IJAREMS

JOURNAL HOMEPAGE

Full Terms \& Conditions of access and use can be found at http://hrmars.com/index.php/pages/detail/publication-ethics 


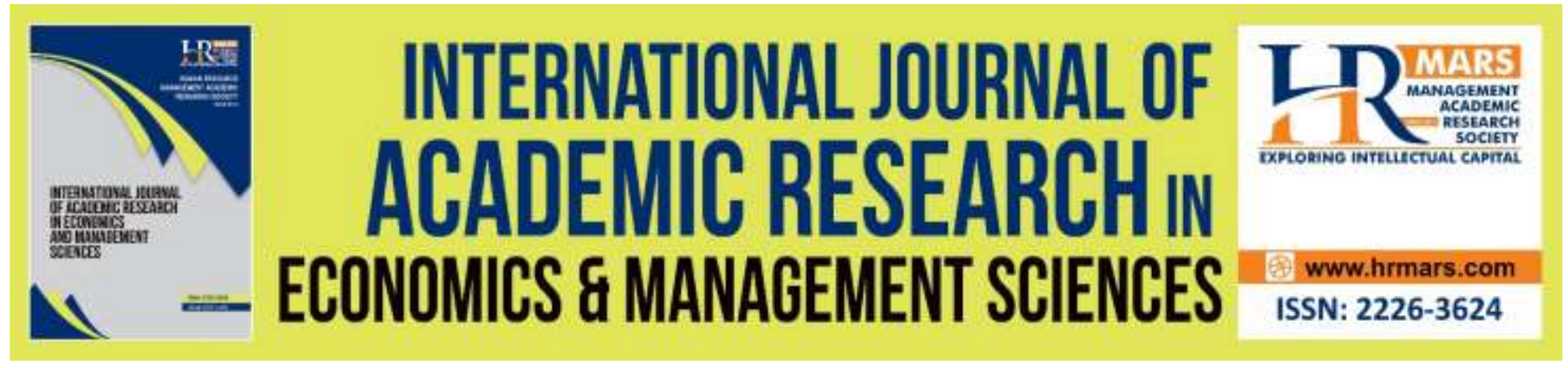

\title{
Human Capital Investment in Bangladesh: Issues and Options
}

\author{
Muhammad Helal Uddin, Sisheng Xie \\ College of Economics and Management, Nanjing University of Aeronautics and Astronautics \\ Nanjing, China. \\ Email: helaluddin.du@yahoo.com
}

\begin{abstract}
Human capital is regarded as one of the most important determinants for economic growth and development. It is recognized by the level of education and health in a population. This paper analyzes the public and private expenditure on education and health as an investment in human capital. The budgetary allocation is considered here as public expenditure. In contrast, the individual payment towards education and health is considered as a private expenditure. Mainly secondary sources of data have been taken for discussion. The descriptive approach of data analysis has been done to investigate the present situation of human capital investment. The study found that the allocation towards education and health has been increased in terms of quantity in a steady peace over the years. The proportion of public education and health expenditure, as well as the percentage of GDP on education and health expenditure, has been decreased. Finally, it suggests the allocation of more funds especially from the public sector towards education and health. Further, new initiatives and timely steps should be taken as per local and world market demands.

Keywords: Human Capital, Investment, Education, Health, GDP.

\section{Introduction}

The population of a country is considered as an asset. Humans are considered as the most important and significant source of productivity and economic growth (Ali, Alam, \& Noor, 2016). National economic growth totally depends on the extent to which its population becomes human capital. Other than economic growth, here are also some other spill-over effects and externalities of human capital investment like technological, spatial, environmental, economic and noneconomic (Wilson, \& Briscoe, 2004). The standard of national human capital depends on national education and health standard. According to the organization for economic cooperation and development (OECD), human capital is the knowledge, skills, competencies, and attributes
\end{abstract}


embodied in individuals or groups of individuals that facilitate the creation of personal, social and economic well-being.

Bangladesh is one of the most densely populated countries in the world. The population density per square kilometer in Bangladesh is almost 1290 people. The current population living in the country is over 168 million. It contains the world's $2.18 \%$ of people with a very tiny fraction of its land area of 130,170 Km2 (CIA, 2018). The population growth rate is increasing at a slower pace at an average of 1.05 percent per year. It has been projected that the country's population will be reached at its landmark of 200 million within the next few decades. The labor force participation rate is being consistent at 58 million over the years. The unemployment figure is around 2.6 million over the years. It is fluctuating between the rates of 4 to 5 percent of the labor force participation rate since the 1990s. The underemployment rate from the 1990s is on average $25 \%$ till now (labor force Survey, BBS, 2018). Underemployment rate can be calculated by measuring the visible unemployment and invisible unemployment (Islam, 2014.). The higher underemployment rate is really a matter of concern, especially for national policymakers. Most of the people among the employed groups are engaged in the informal sectors. The number will be around two-third of the employed person. Among the remaining one-third, half of them are regular paid workers and the rest are working as daily labors.

The people of Bangladesh are mainly young and in the working age. Almost $65 \%$ of the population lies between the ages of 15-64 which is considered as the working age of the population of a country. Even the number of 25+ people is also highest among the age structures of the population. The number of children aged below 14 is $27 \%$ indicating that Bangladesh has a strong supply line of the labor force in the coming years. The population pyramid of Bangladesh clearly indicates the future possibilities of economic growth and prospects. A higher rate of growth will only ensure when the country will arrange more investment in human capital. According to the population characteristics of Bangladesh by the level of education in the year 2016-17, around 34 million people among the 160 million does not have any education. The highest number of 38 million people has only a secondary level of education followed by the primary pass of 24 million. Only 8 million people have higher secondary and 4.55 million have the tertiary level of education. The gloomy picture is that only $2.85 \%$ of the population has higher education and the secondhighest proportion does not have any education (Labor force survey, 2016-17, BBS). This situation clearly demands more allocation and distribution of education.

The accessibility of all levels of education is still unreachable due to the cost of education. Especially, the higher cost of tertiary education shifts the students back from the track. The dropout rate after primary and the secondary level is higher. Large numbers of causes are suitable in this situation. Household poverty is one of them. After the secondary level, one of the main causes of dropping-out is the opportunity of more earning without higher education. The number of educated unemployment has become a serious problem now a day. A number of secondary graduates generally leave the country towards a foreign country for higher earning. The country's main source of foreign currency is the expatriate's remittance from abroad. Higher education subsidy from the government is stagnant and insufficient to mitigate the increasing demand for the tertiary level. 
Under these circumstances, improving human capital by investing in education, health, and some other related field is a key issue for Bangladesh. The age structure and the age-education workforce clearly demand more pragmatic steps and patron towards human capital improvement. Addressing the unemployment rate into a tolerable level needs a much practical and visionary plan. The HDI position of Bangladesh is not satisfactory even within the South-Asian countries. There are no near alternatives without improving the human capital to face domestic and globalization challenges.

This paper aimed to investigate the present status of Bangladesh's human development among the South Asian countries and looking for reasons for whether the insufficient allocation towards education and health is caused by the countries' lower economic position. Previous studies showed the relationship between education spending and economic growth. A few studies have been conducted on the sources of the fund disbursement and the relationship between the human capital situation and the allocation towards the human capital. The goal of this study, therefore, is to find out how Bangladesh is financing its human capital from the individual to the state level. The recent issues and different situations of investment in human capital will be examining here thoroughly. The possibilities and options regarding the improvement of human capital have tried to inspect carefully. It also focuses on the different stakeholder's investment in the formation of human capital. Specifically, this research will elaborate: 1) Public spending on education and health and its composition.2) Private expenditure on education and health and its composition. 3) Some policy proposals to improve the present situation at the desired level. 4) Finding further study areas for future issues on the country's human development.

\section{Literature Review}

Adam Smith (1776) is one of the first classical economists who introduced the term human capital in his definition of capital. Like the capital stock, human skills also increase the wealth of the nation as well as the individuals (Laroche, Merette, \& Ruggeri, 2001). Human capital is determined by education, training, medical treatment, and if effectively a means of production. Increased human capital indicates the differentials of income for graduates. Human capital is also important for influencing rates of economic growth (Becker, S. Gary, 1975). According to the Oxford Dictionary, human capital is the skill, the labor force possesses and is regarded as a resource or asset. It encompasses the notion that spending on people is an investment in education, training, health, etc. and that investment increases human productivity. Laroche, Merette, and Ruggeri, (2001) explain the basic characteristics of human capital. According to him, human capital is a complex and multi-faceted concept. It consists of distinctive abilities and acquired knowledge. The abilities, for example, intellectual, physical and psychological aptitudes which have been given by birth of a man are called innate ability. It is the stock of skills that the labor force possesses. Investment in human capital generally refers to the expenditure on education, training, and health (Goldin, 2016).

Education is the most important form of investment in human capital (Weil, 2013). It is like other types of investment decisions. Every investment requires an initial endowment of capital. When the return from education will be greater than the cost associated with it, expenditure on human 
capital will be prevalent (Blundell, Dearden, Meghir, \& Sianesi, 1999). According to Khan (2007), the higher growth rate of East Asian countries over the average world rate during early 2000 was mainly due to the large volume of highly skilled human capital. Initially, they invested a huge amount on education, research and development, health, youth development, and some other sectors. With the accumulation of a high volume of human resources, they have been able to attract a large number of multi-national companies which eventually help them to boost economic growth. About one-third of the world population is living in the Asia-Pacific region. Large varieties of development to the under-development economy are found here. Rayn, A. (2010) found an institutional contribution to form the human capital in the developing region. He emphasized the sustainability of human development through building future generations, guiding policy development, supporting community and using academic freedom.

Kucharcikova, (2014) investigates the investment in human capital as a source of economic growth. Investment in education brings intensive economic growth by ensuring higher production, services, quality, labor- productivity, cost advantages, innovation, and relationship with new customers and the ability of the competition on the market. Islam, (2014) examines the causal relationship between education and national income growth between the years of 19732010 using a multivariate approach. He found uni-directional causality from GDP to education and vice-versa. GDP and education can cause each other to grow. This relation indicates the longrun equilibrium relationship between GDP and the components of the education expenditures. Ali, Alam, \& Noor, (2016) found a significant relationship between economic growth and government expenditure on education and health in Bangladesh. Asadullah (2006) found a $7 \%$ labor market additional year of return to education. He analyzed the rate of return of the education and found the maximum return at the primary level compared to the other sectors of education. The highest return of education is from the female compared with the male (Psacharopoulos, 2018).

Rahman and Al-Hasan (2018) try to estimate the return to the schoolings from the context of Bangladesh. He uses the quantile regression and instrumental variable regression model to find out the return to schooling. Due to the endogeneity problem, the return has been underestimated and tends to vary along with the wage distribution. He also found the female higher average return of schooling than the male. However, the returns are also high for both of the male and female when they move alone higher percentiles of the wage distribution. Raima Nazar (2018) conducted a microanalysis of the return to the investment in education using random samples in the Multan district of Pakistan. She found a positive and significant role of education investment in the wage earner's earning. The female earning is higher than the male with the same level of investment. The higher-earning is also for the English medium graduates compare to the mother language medium learners

The widely used human development measurement indicator is the human development index (HDI). Generally, the long and healthy life, access to knowledge and the standard of living are measured by the index. A healthy life is accessed by the life expectancy at birth while the knowledge is measured by the average years of schooling. Gross national income is the assessment tool of the standard of living of a country. The HDI values indicate the condition and 
rank of the human development of a country. In 2017, the value of HDI is 0.608 for Bangladesh positioning 136 out of 189 countries in the world. Bangladesh is staying below the average of the medium human development countries value of 0.645 and South Asian countries average of 0.638. In the Asian country ranking, Bangladesh is ahead of Nepal and Pakistan. Nepal has 0.574 and Pakistan has 0.562 indexes value positioned 149 and 150 of the country ranking. The life expectancy of Bangladesh is much higher from these two countries although per capita income is lower than Pakistan. In the same year of the HDI ranking, Sri Lanka stood first among the SouthAsian countries positioning 76 of getting 0.776 index value. Maldives and India stood 101 and 130 positions respectively. Then Bhutan, Bangladesh, Nepal, Pakistan, and Afghanistan are chronologically positioned. The value of the HDI index of Afghanistan is 0.498 and the position is 168 in the ranking (HDI-2017)

\section{Current Situation of Human Capital Investment in Bangladesh Status of Socio-Economic Progress}

Bangladesh has been able to maintain the upper rate of growth over the decades amidst the slow rate of growth in the world. According to the international monetary fund in its world economic outlook 2018, global growth was picked at 3.8 percent in 2017, slightly slowed down to 3.6 in 2018. Bangladesh is experiencing above $6 \%$ growth rate over this decade. Now the growth of the total domestic products is above $7.5 \%$. It has been projected that the growth will continue its journey towards up-word and expects to touch it's landmark double-digit within the next few years. Bangladesh has recently been upgraded from the least developed country list toward the developing country. The economy of Bangladesh is now 302 billion US\$. Per capita income crosses over 1000 USD in 2014. Since then the average income is increasing and within this decade it will be above the 2000 USD landmark.

Life expectancy at birth has grown continually and reached 73 years from the 65 years within the last two decades. The total literacy rate was only $45 \%$ in 2000 that increased tremendously to $73 \%$ in the year of 2018 . This figure clearly demands more pragmatic steps toward mass education. Country's positive picture prevails in the poverty rate. The rate has continued to decrease from one half to one fifth within the last eighteen years. Robust growth of foreign remittance inflow and export growth of the readymade garments industry leads the downslides of the poverty rate for those days. 
INTERNATIONAL JOURNAL OF ACADEMIC RESEARCH IN ECONOMICS AND MANAGEMENT SCIENCES Vol. 8, No. 3, 2019, E-ISSN: 2226-3624 @ 2019 HRMARS

Table 1: Different economic indicators

\begin{tabular}{|c|c|c|c|c|c|c|}
\hline Year & $\begin{array}{l}\text { GDP } \\
\text { Growth }\end{array}$ & $\begin{array}{l}\text { GDP per } \\
\text { capita USD }\end{array}$ & $\begin{array}{l}\text { Per capita income USD } \\
\text { (Atlas Method) }\end{array}$ & $\begin{array}{l}\text { Poverty } \\
\text { Rate (\%) }\end{array}$ & $\begin{array}{l}\text { Literacy } \\
\text { rate (\%) }\end{array}$ & $\begin{array}{l}\text { Life Expectancy } \\
\text { (Year) }\end{array}$ \\
\hline 2000 & 5.9 & "2405 & "2420 & "48.9 & "45 & "65.3 \\
\hline 2001 & 5.08 & 400 & 440 & 47.6 & 47.5 & 65.9 \\
\hline 2002 & 3.83 & 402 & 440 & 45.5 & 48.3 & 66.4 \\
\hline 2003 & 4.74 & 432 & 460 & 43.8 & 49.5 & 66.9 \\
\hline 2004 & 5.24 & 460 & 510 & 41.4 & 50.2 & 67.4 \\
\hline 2005 & 6.54 & 484 & 550 & 40.2 & 51.6 & 67.9 \\
\hline 2006 & 6.67 & 494 & 570 & 38.4 & 52.3 & 68.4 \\
\hline 2007 & 7.06 & 541 & 610 & 36.8 & 53.3 & 68.8 \\
\hline 2008 & 6.01 & 637 & 660 & 35.1 & 54.4 & 69.3 \\
\hline 2009 & 5.05 & 703 & 730 & 33.4 & 55.5 & 69.7 \\
\hline 2010 & 5.57 & 780 & 800 & 31.5 & 56.8 & 70.1 \\
\hline 2011 & 6.46 & 860 & 890 & 29.9 & 55.8 & 70.6 \\
\hline 2012 & 6.52 & 880 & 970 & 28.5 & 56.3 & 71 \\
\hline 2013 & 6.01 & 976 & 1040 & 27.2 & 57.2 & 71.4 \\
\hline 2014 & 6.06 & 1110 & 1110 & 26.0 & 58.6 & 71.8 \\
\hline 2015 & 6.55 & 1236 & 1220 & 24.8 & 63.6 & 72.1 \\
\hline 2016 & 7.11 & 1385 & 1370 & 24.3 & 71.0 & 72.4 \\
\hline 2017 & 7.28 & 1544 & 1520 & 23.1 & 72.3 & 72.8 \\
\hline 2018 & 7.86 & 1675 & 1750 & 21.8 & 73 & 73 \\
\hline
\end{tabular}

Sources: World Bank. UNESCO Institute for Statistics. Ministry of Finance. Bangladesh.

\section{Public Expenditure on Human Capital}

Recently Bangladesh has been given more emphasis on human capital development due to face the globalization challenges. The government of Bangladesh sets its highest priority to improve the human into skill human capital alone with economic growth. The government is allocating more on the human capital development sectors such as education, technology, health, family welfare, etc. Various programs have been taken to enhance the quality of skill and human resources by allocating more on primary and mass education, secondary, tertiary, vocational education and training. The government has given the highest priority to the education sector. The national education policy 2010 has been taken to build the nation as an educated, creative and skilled. Around 24 percent of the national budget has been allocated to the human resources 
related sectors. (Bangladesh economic review, 2017). The government has been implementing various programs and projects in the education sector to achieve sustainable development goals (SDG). Third Primary Education Development Program (PEDP-III) is ongoing to ensure the quality of primary education. To ensure maximum enrollment, regular attendance and reducing dropout rates are the main objectives of that program. Feeding at school and stipend programs for primary students have been taken to the children of hard to reach areas to make the education accessible and to ensure regular attendance among 104 upojila (Police station). Additionally, the monthly stipend program is going on from the last decade at the secondary level to prevent dropout rates and ensure gender equality. Moreover, female students are getting full tuition fee-free up to degree level. Free textbooks are distributing among primary and secondary school students over the last several years. The government has allocated more funds to construct new academic buildings all over the country. Especially, initiatives have been taken to establish public universities in every district of the country. Education quality enhancement programs such as teachers' training, development of training infrastructure and ICT based learning methodology are implementing. Gradual emphasis on establishing vocational education and training institutions and more priority has been given to provide TVET education.

Table 2 shows the Bangladesh government's budgetary allocation on education, health, and human resources from the year 2008-09 to the current fiscal year. Data of 2019-20 shows the proposed allocation and 2018-19 shows the revised budget. The remaining are the actual figures which have been once proposed and then revised. The growth of the budget is much higher during the last several fiscal years. Since the independence of the country in 1971, the figures for the budgets were not too high. In the last year of the previous decade, the amount of budget crossed over one thousand billion or one trillion BDT for its first time. After that, the amount has increased rapidly and within the next 4 years, it overlapped the two thousand billion or two trillion BDT. Further, it took only another 5 years to reach five trillion reflects the tremendous growth of the budgetary allocation of the different sectors among the country. 
INTERNATIONAL JOURNAL OF ACADEMIC RESEARCH IN ECONOMICS AND MANAGEMENT SCIENCES Vol. 8, No. 3, 2019, E-ISSN: 2226-3624 @ 2019 HRMARS

Table2. Budgetary allocation on education, health and human capital (BDT Billion)

\begin{tabular}{|c|c|c|c|c|c|c|c|}
\hline FY & $\begin{array}{c}\text { National } \\
\text { Budget } \\
\text { (Billion) }\end{array}$ & $\begin{array}{l}\text { National } \\
\text { Education } \\
\text { Budget } \\
\text { (Billion) }\end{array}$ & $\begin{array}{l}\text { Education } \\
\text { Budget as a } \\
\% \text { of total } \\
\text { Budget }\end{array}$ & $\begin{array}{l}\text { National } \\
\text { Health } \\
\text { Budget } \\
\text { (Billion) }\end{array}$ & $\begin{array}{l}\text { Health } \\
\text { Budget as } \\
\text { a \% total } \\
\text { Budget }\end{array}$ & $\begin{array}{c}\text { Allocation } \\
\text { on Human } \\
\text { Resources } \\
\text { (Billion) }\end{array}$ & $\begin{array}{c}\text { Allocation } \\
\text { on HR as a } \\
\% \text { of total } \\
\text { Budget }\end{array}$ \\
\hline & 893.16 & & & & & & \\
\hline 2008-09 & & 118.69 & 13.29 & 51.1 & 5.71 & 211.06 & 23.63 \\
\hline 2009-10 & 1016.08 & 155.50 & 15.32 & 62.71 & 6.18 & 267.58 & 26.36 \\
\hline 2010-11 & $1,282.68$ & 183.83 & 14.33 & 72.87 & 5.68 & 317.38 & 24.74 \\
\hline 2011-12 & $1,526.64$ & 187.44 & 12.27 & 76.67 & 5.02 & 332.81 & 21.80 \\
\hline $2012-13$ & $1,744.48$ & 264.98 & 13.82 & 91.30 & 4.82 & 382.81 & 20.22 \\
\hline 2013-14 & $1,986.21$ & 262.36 & 13.22 & 97.54 & 4.91 & 456.56 & 22.99 \\
\hline 2014-15 & $2,088.74$ & 251.70 & 12.05 & 83.92 & 4.02 & 503.65 & 24.11 \\
\hline $2015-16$ & $2,408.07$ & 336.69 & 13.98 & 102.51 & 4.26 & 648.24 & 26.92 \\
\hline 2016-17 & $2,772.36$ & 383.97 & 13.85 & 103.41 & 3.73 & 759.99 & 27.41 \\
\hline $2017-18$ & $3,218.62$ & 384.95 & 11.96 & 130.36 & 4.05 & 808.15 & 24.98 \\
\hline 2018-19 & $4,425.41$ & 464.22 & 10.49 & 172.69 & 3.90 & 1097.76 & 24.81 \\
\hline $2019-20$ & $5,231.90$ & 536.80 & 10.26 & 199.44 & 3.81 & 1290.56 & 24.67 \\
\hline
\end{tabular}

Source: Bangladesh National Budget Speech 2013-14, 2019-20. Ministry of Finance. 
National Education Budget reflects the allocation of the Ministry of education and the Ministry of primary and mass education. The government has proposed 536 billion BDT in this current fiscal year. During the years of 2016-18, the allocation was sluggish at 384 billion BDT. The allocation of the education budget is decreasing over the years in terms of percentage of the total budget. The rate was above 15 percent in the year 2009-10. Over time, the percentage allocation has decreased and currently, it stays at 10.26 percent which is the lowest among all the previous fiscal years. However, according to UNESCO, the allocation should be at least $20 \%$ of the total distribution. Bangladesh is clearly much below the standard allocation. The rate is lower even among the South Asian countries. There is no other alternative to spend more on this sector if the government really wants to improve the standard of its human. Education is positively related to the standard of living and the gross domestic product. Although the country's economic growth is highly satisfactory at this current stage. There are several other factors behind the robust growth. To sustain economic growth, Bangladesh must need to allocate more on education.

National Health Budget reflects the allocation towards the Ministry of Health and Family welfare as well as the health service division. In the current fiscal year, the proposed budget towards the health sector is 199.44 billion BDT which is only 3.81 percent of the total budget. The disbursement to the health sector is much lower in terms of the population. Although Bangladesh has already achieved the Millennium Development Goal (MDG) health-related targets (Bangladesh economic review, 2018). Ten years ago the allocation was above 6 percent. It is unfortunate to decrease the proportion in the last several consecutive budgets. According to the Bangladesh National Health Account, health expenditure as a source of government financing was $26 \%$ in 2007 while household out-of-pocket spending was 64\%. Remaining 10\% were from foreign donation, through some NGOs and private volunteer firms (Ravi, Rannan-Eliya, 2007). Bangladesh's government has been taken various health-related programs to achieve the millennium development goal. Already Bangladesh has successfully reduced fertility and the maternal mortality rate. The average life expectancy of people has also increased with the availability of safe drinking water, a sanitation system has achieved the target.

The last two columns of table 2 express the share of Human Resources and their percentages in the budgets. Total development and the non-development budgets on human resources are shown here. Government allocation of human resources includes the human resource development (HRD) related sectors such as ministry of primary and mass education, secondary and higher education division, technical and madrasah education division, ministry of science and technology, health service division, ministry of health and family welfare, ministry of women and children affairs, ministry of social welfare, ministry of labor and employment, ministry of expatriates welfare and overseas employment, ministry of cultural affairs, ministry of youth and sports and different some other divisions and sectors. The average distribution is almost 25 percent of the total budget all over the years. The highest disbursement was 26.36 percent and the lowest was 20.22 percent in the year 2009-10 and 2012-13 fiscal year consecutively.

The government annual development program (ADP) reflects its commitment towards the targeted goal of the country. Bangladesh has been given more priority to improve the skill and overall quality of its population. In the year of 2011-12, the allocation of ADP towards human 
INTERNATIONAL JOURNAL OF ACADEMIC RESEARCH IN ECONOMICS AND MANAGEMENT SCIENCES Vol. 8, No. 3, 2019, E-ISSN: 2226-3624 @ 2019 HRMARS

development was only 93.65 billion BDT. The amount towards HD has increased with the allocation of budget and ADP. It reached at 556.15 billion BDT in the fiscal year 2019-20. The percentage of ADP on HD stood 27.4 and the percentage of the total Budget is 10.63. This is the highest allocation of HD as a percentage of ADP and in the total budget all over the years. The average distribution of human development share on ADP is $25 \%$ and almost the same over the decades with slight ups and downs. Where's, the trend of HD as a \% of total Budget is reached at double-digit in the current fiscal year which was 8 and 7 percent in the year 2016-17 and 2011213 fiscal year respectively.

Table3. Budgetary allocation of ADP on the Human Development (in Billion BDT)

\begin{tabular}{|c|c|c|c|c|c|c|c|c|c|}
\hline Year & $2019-20$ & $\begin{array}{l}2018- \\
19\end{array}$ & 2017-18 & $\begin{array}{l}2016- \\
17\end{array}$ & $\begin{array}{l}2015- \\
16\end{array}$ & $\begin{array}{l}2014- \\
15\end{array}$ & $\begin{array}{l}2013- \\
14\end{array}$ & $\begin{array}{l}2012- \\
13\end{array}$ & $\begin{array}{l}2011- \\
12\end{array}$ \\
\hline \multicolumn{10}{|l|}{$A D P$} \\
\hline & $2,027.21$ & 1,670 & $1,195.38$ & 903.09 & 816.12 & $6,49.19$ & 648.70 & 523.66 & 410.80 \\
\hline $\begin{array}{l}\text { Human } \\
\text { Development }\end{array}$ & 556.15 & 421.73 & 234.46 & 221.87 & 170 & 162.20 & 151.40 & 123 & 93.65 \\
\hline HD as a $\%$ of ADP & 27.4 & 25.3 & 19.6 & 24.6 & 20.8 & 25 & 23.3 & 23.5 & 22.8 \\
\hline $\begin{array}{l}\text { HD as a \% of total } \\
\text { Budget }\end{array}$ & 10.63 & 9.53 & 7.29 & 8 & 7.06 & 7.77 & 7.63 & 7.06 & 6.14 \\
\hline
\end{tabular}

Source: Ministry of Finance. Bangladesh.

Government expenditure on education and health as a \% of GDP is shown in table 4. The average government education expenses as a percentage of GDP is around $2 \%$. The figure is around $1 \%$ in the case of health expenses. Total health expenses indicate both of the public and private spending information. Even the contribution of private sectors towards education and health is somehow unavailable. It can be easily separate the contribution of the private sector if the total information were available. However, public and private health expenses in-terms of GDP are 2.46 percent which indicates private expenditure was 1.65 percent of GDP in 2013.

Table 4: Government expenditure on education and health as a proportion of GDP

\begin{tabular}{|c|c|c|c|c|c|c|c|c|}
\hline Year & 2013 & 2012 & 2011 & 2009 & 2008 & 2007 & 2006 & 2004 \\
\hline $\begin{array}{l}\text { Public Education expenses as a \% of } \\
\text { GDP }\end{array}$ & 1.96 & 2.18 & 2.13 & 1.94 & 2.05 & 2.20 & 2.13 & 1.94 \\
\hline Public Health expenses as a \% of GDP & 0.81 & 0.98 & 1.04 & 0.99 & 0.95 & 0.99 & 1.04 & 1.04 \\
\hline Total Health expenses as a\% GDP & 2.46 & 2.49 & 2.50 & 2.57 & 2.49 & 2.40 & 2.34 & 2.32 \\
\hline
\end{tabular}

Source: World Bank.

Table 5 shows the expenditure on Primary, Secondary and Tertiary education as a \% of government expenditure on education. The highest priority has been given to primary education 
INTERNATIONAL JOURNAL OF ACADEMIC RESEARCH IN ECONOMICS AND MANAGEMENT SCIENCES Vol. 8, No. 3, 2019, E-ISSN: 2226-3624 ㄷ 2019 HRMARS

followed by the secondary and tertiary levels. Almost half of the government allocation is distributed to primary education. Secondary education also gets similar kinds of concentration. It is worldwide recognized that the rate of return of primary education is much higher than the secondary and tertiary levels (Psarchopolous, 2018. Asadullah, 2007).

Table 5: Expenditure on Primary, Secondary and Tertiary as a \% of government expenditure on education

\begin{tabular}{lccccccccc}
\hline \hline Year & 2016 & 2012 & 2011 & 2009 & 2008 & 2007 & 2006 & 2004 & 2003 \\
\hline \hline Primary & 43.50 & 44.60 & 47.14 & 44.73 & 44.73 & 46.25 & 41.96 & 39.99 & 45.43 \\
Secondary & 35.43 & 39.10 & 41.14 & 40.21 & 39.59 & 40.78 & 43.42 & 48.47 & 45.46 \\
Tertiary & 20.00 & 14.73 & 10.29 & 13.50 & 13.26 & 11.47 & 12.93 & 11.54 & 9.11 \\
\hline
\end{tabular}

Source: UNESCO Institute for Statistics.

It is worth allocating more on the initial stage of education. The primary education of Bangladesh is totally free and the government is bearing all of the expenses including free textbooks and meals in the school. There are also non-government institutions like kinder-garden, English medium, Arabic medium and some NGOs who are providing primary education in the country. The share of tertiary education received one-fifth of the fund during the year 2016. From the beginning of this decade, tertiary education is giving more importance. In 2012, the share was $15 \%$ and has reached $20 \%$ in the year of 2016 . The government is trying to engage the private sector more in tertiary education.

Table 6: Successful completion rate of Primary, Secondary and Higher Secondary education

\begin{tabular}{llllllllll}
\hline \hline Year & 2018 & 2017 & 2016 & 2012 & 2011 & 2009 & 2008 & 2007 & 2006 \\
\hline \hline Primary & 81.40 & 81.15 & 81 & 80.6 & 80.1 & 79.4 & 73.9 & 70.3 & 61.5 \\
Secondary & 63.11 & 62.89 & 61.70 & 59.71 & 58.41 & 56.82 & 53.35 & 46.72 & 44.74. \\
H. Secondary & 80.37 & 80.11 & 79.92 & 79.3 & 78.63 & 77.82 & 78.20 & 65.87 & 62.64 \\
\hline \hline
\end{tabular}

Source: BANBAIS, 2018.

\section{Private Expenditure on Education and Health}

There is an insufficiency of relevant data for the private individual expenditure on education and health. This is due to the proper survey and steps. The expenditure also varies from individual to individual depending on their income and consumption habit. The availability of the relevant 
INTERNATIONAL JOURNAL OF ACADEMIC RESEARCH IN ECONOMICS AND MANAGEMENT SCIENCES Vol. 8, No. 3, 2019, E-ISSN: 2226-3624 ㄷ 2019 HRMARS

service is also one of the causes of expenditure differentials. Basically, the average expenditure differs largely between the dweller of the city and the rural village area. Some other types of data are presented here which endeavors to focus on the individual spending on education and health.

Table 7: Average monthly income, expenditure, and consumption of household

\begin{tabular}{cllll}
\hline \hline \multirow{2}{*}{ Survey Year } & \multicolumn{2}{c}{ Residence } & \multicolumn{3}{c}{ Average Monthly (Taka) } \\
\cline { 3 - 4 } & \multicolumn{1}{c}{ Income } & Expenditure1 & Consumption \\
\hline \hline 2016 & National & 15,945 & 15,715 & 15,420 \\
& Rural & 13,353 & 14,156 & 13,868 \\
& Urban & 22,565 & 19,697 & 19,383 \\
& National & 11,479 & 11,200 & 11,003 \\
& Rural & 9,648 & 9,612 & 9,436 \\
& Urban & 16,475 & 15,531 & 15,276 \\
& National & 7,203 & 6,134 & 5,964 \\
& Rural & 6,096 & 5,319 & 5,165 \\
& Urban & 10,463 & 8,533 & 8,315 \\
& National & 5,842 & 4,886 & 4,542 \\
& Rural & 4,816 & 4,257 & 3,879 \\
& Urban & 9,878 & 7,360 & 7,149 \\
\hline \hline
\end{tabular}

Sources: Household income and expenditure survey (2016).

*1. Consumption plus lumpy life-cycle expenditures, income tax, interest charges, and insurance. In the year 2016, the average per capita income of a household was 15,945 BDT. Almost all of the income was spent in different consumption sectors. The expenditures were 13,868 BDT in rural and 19,383 BDT in the urban area. The average monthly income and consumption expenditure of households has increased 3 times during the years 2000-2016. Within the same years, the expenditure on health and education also increased proportionately.

Table 8: Household expenditure on different sub-sectors.

\begin{tabular}{|c|c|c|c|c|c|c|c|c|c|c|}
\hline \multirow{2}{*}{$\begin{array}{l}\text { Year of } \\
\text { Survey } \\
\text { and } \\
\text { Residence }\end{array}$} & \multirow[b]{2}{*}{$\begin{array}{l}\text { Avg. } \\
\text { Cons. } \\
\text { Exp. }\end{array}$} & \multicolumn{4}{|c|}{ Major Expenditure Groups (\%) } & \multirow[b]{2}{*}{$\begin{array}{l}\text { Fuel \& } \\
\text { Lighting }\end{array}$} & \multirow[b]{2}{*}{$\begin{array}{l}\text { Household } \\
\text { Effect }\end{array}$} & \multirow[b]{2}{*}{ Medical } & \multirow[b]{2}{*}{ Education } & \multirow[b]{2}{*}{ Mis. } \\
\hline & & Total & $\begin{array}{l}\text { Food } \\
\text { and } \\
\text { Beverage }\end{array}$ & $\begin{array}{l}\text { Cloth } \\
\text { Foot } \\
\text { wear }\end{array}$ & $\begin{array}{l}\text { Housing } \\
\text { House } \\
\text { Rent }\end{array}$ & & & & & \\
\hline \multicolumn{11}{|l|}{2016} \\
\hline National & 15420 & 100 & 47.69 & 7.12 & 12.43 & 6.07 & 2.93 & 4.54 & 5.42 & 13.80 \\
\hline Rural & 13868 & 100 & 50.49 & 7.50 & 9.80 & 6.65 & 2.88 & 4.63 & 4.93 & 13.12 \\
\hline Urban & 19383 & 100 & 42.59 & 6.42 & 17.25 & 5.02 & 3.03 & 4.36 & 6.33 & 15.00 \\
\hline \multicolumn{11}{|l|}{2010} \\
\hline National & 11003 & 100 & 54.81 & 4.95 & 9.93 & 5.63 & 1.68 & 3.79 & 5.68 & 13.53 \\
\hline Rural & 9436 & 100 & 58.74 & 5.12 & 7.29 & 6.06 & 1.85 & 4.05 & 4.18 & 12.71 \\
\hline Urban & 15276 & 100 & 48.19 & 4.67 & 14.41 & 4.89 & 1.40 & 3.35 & 8.20 & 14.8 \\
\hline
\end{tabular}

Sources: Household income and expenditure survey (2016).

The majority portions of the household income spent on the food and beverage. Table 8 shows that almost $48 \%$ are spending on that. The accommodation and cloth take another $20 \%$ of the consumption expenditure. The percentage of spending on education and health was only 5.42 and 4.52 respectively. Education spending decreased slightly in 2016 compared to spending in 
2010. The reverse situation happens in case of medical expenditure between those two years. Almost two-thirds of the health expenditure is the household private expenditure on the different formal and informal sector. One-third of the expenditure is born by different other organizations. Government, NGO, and foreign donors are among them. The government provides a comprehensive health service alone with policy and regulations. There are a large number of non-government organizations (NGOs) providing necessary health services to the poor. The donor communities are also playing a significance role and technical assistance to provide the primary health care facilities (Hossain, 2015).

Table 9: Per Household and Per Capita Expenditure on Education

\begin{tabular}{llll}
\hline \hline Residence & $\begin{array}{l}\text { Per Household Expenditure on } \\
\text { education (BDT) }\end{array}$ & Male & Percent of Expenditure Incurred by Sex \\
\cline { 3 - 4 } & & 53.73 & 46.27 \\
\hline \hline National & 925 & 57.96 & 42.04 \\
Rural & 604 & 49.78 & 50.22 \\
Urban & 1796 & Female \\
\hline \hline
\end{tabular}

Sources: Household income and expenditure survey (2010).

The expenditure on education per household and the percentage of educational expenditure for both male and female were presented in table 9. The average expenditure on education per household stood 925 BDT. In the urban areas, the expenditure was 1796 and in the rural area, it was 604. At the national level, 53.73 percent of educational expenditure was incurred for males and 46.27 percent for females. Female education expenditure was larger than males in the urban area compared to the male education expenditure in the rural area. Previous study reveals that female education has a higher return than the male all over the world. On the other hand, the early marriage of the female in the rural area caused the lower proportion of education expenditure on them.

\section{Policy issues for Human Capital Investment in Bangladesh}

Bangladesh has been blessed by the continuous supply of working-age labor force. Unfortunately, the maximum of the labor force is either uneducated or only has primary education. The numbers of higher secondary and tertiary graduates are very low compared to the primary educated and uneducated people. Two-third of the employed people are working in the informal sectors and on a daily basis. The socio-economic indicators are still positive and growing strongly overtimes. The main factors behind this are a strong inflow of expatriates foreign remittance and the robust growth of the ready-made garments industry.

The position of Bangladesh is much below in the Human Development Index. Bangladesh is experiencing positive economic growth amidst a decreasing allocation rate towards the education and health sectors. Education and health budget as a \% of the total budget and in terms of GDP is decreasing over time. Especially, public education expenditure as a \% of total GDP is on average around $2 \%$ and currently is below the $2 \%$ mark. This is the lowest among the South Asian region which is indicating less commitment towards education as well as research and development. 
Allocation on the human resource is stagnant at a fixed percent over the years. The budgetary allocation of ADP on human development has reached double-digit for the first time. Implementation of ADP on human resources development is not satisfactory. There is a huge difference between the proposed budget and the actual budget every year. This is mainly due to the lack of implementing capacity.

Initially, Bangladesh has given more priority on primary education and the allocation is still top among the types of education. Over time, secondary education is also in the more priority level. The main motive of higher allocation in the secondary level is to prevent the drop-out rate and help to reach the student to the tertiary level. The higher education of the country especially the private tertiary education is too much costly and beyond the reach from the lower-middleincome group. Although the government is giving a huge subsidy only to the public universities, still it is insufficient in terms of the number of students seeking higher education. Even the government is trying to promote the TEVT but the quality and the service of the program are not satisfactory.

Public health expense as a percentage of total expenses is very low and much below the $5 \%$ level. The allocation of the health sector is decreasing over time. Private expenditure towards human capital is only ten percent of individuals earning. The larger portion of income goes to food, cloth, and housing purposes. Private household expenditure on education differs widely between the rural and urban areas. The quality of education and health service, as well as the availability, are insufficient in the rural area to compare with those in the city. The huge influx of city migration over the years is also to ensure the quality education and availability of health services with more employment opportunities.

\section{Further Study}

The study has revealed that the economic indicators like GDP, per capita income, poverty situation have improved remarkably amidst the decreasing proportion of allocation towards education and health. Prospective researchers can try to analyze this negative relationship between the various economic indicators and the percentage allocation of human capital investment in Bangladesh.

\section{Recommendations}

A pragmatic long term plan should be taken for the existing and the upcoming labor force to face the challenge of globalization and to ensure continuous growth and development of the country. Especially, national human resource policy and an action plan need to be taken immediately. Unemployment, under-employment and more engagement in the informal sector need to address seriously by improving the quality and skills of the human capital. Almost $80 \%$ of export earning comes from the ready-made garments industry. The economy needs diversified skilled human capital for its different sectors to decrease the dependency on earning from one sector.

Bangladesh needs to give more concentration to improve the parameters of its Human Development Index. The government should have a plan to raise the proportion of public 
education budget at least 4 to 6 percent of the GDP or 20 percent of the total budget. Quality education should be ensured in government primary schools. More concentration has to give towards the secondary level to prevent the drop-out rate. It is essential to deploy an adequate number of teachers to ensure the teacher-learner ratio and provide the proper training. A sufficient amount of funds should be allocated to the secondary, tertiary and vocational education. TEVT needs to give more priority and should be more market-oriented. The cost of the private university should be in the range of all walks of the people. Implementation of ADP on human development ought to be effective, efficient and properly within the stipulated time. More funds should be sanction to the different sectors of human development to ensure higher growth and development in the coming future.

Bangladesh has achieved a lot in the health sector but still needs to be achieved in the future. A national health insurance policy and central health information system are the urgent demand. Public health services ought to be broadened. The amount of budgetary allocation is inadequate in terms of the number of population. Private health expenditure is two-third of the total health spending on average. Quality health services need to ensure all service providers amid the lowest possible cost. To prevent the influx of the city, the quality of education and availability of proper health services should be broadening even to remote rural areas. The daily essential cost should be kept on the range of the mass people. Especially the price of food, accommodation, and transportation need to control properly. By the way, people will afford more to spend on the human development sectors and the private spending on education and health will reach up to the mark.

\section{Conclusion}

The present scenario of the human capital investment in Bangladesh is not up to the mark in terms of the public expenses on education, health, and some other key variables. The main asset of the country is only its human. The other forms of natural assets are few and insufficient to mitigate the present needs and future necessities of the vast amount of people. Converting the huge number of people into human capital is only the key solution to tactfully solve the problem. Both public and private awareness have been developed towards the formation of a skilled man. Expenditure on education and health has been increased in terms of absolute terms although the percentage allocation on public expenditure and on GDP is still very low. While private expenses have increased rapidly not only education but also health as well. Bangladesh needs more allocation and distribution towards human capital development both from the public and private sectors to face the fierce challenges of globalization.

\section{Acknowledgment}

This paper was supported by the Scientific Research Base Innovation Fund Program of Nanjing University of Aeronautics and Astronautics in 2018. (No. NJ2018028)

\section{References}

01. Ali, S., Alam, K. J., \& Noor, M. T., (2016). An Econometric Analysis of Human Capital Development and Economic Growth in Bangladesh. Journal of Economics and Sustainable Development. 7(17). 30-38. 
02. Bangladesh Bureau of Education Information and Statistics, (BANBAIS), 2018. Ministry of Education, Government of the people's republic of Bangladesh.

03. Bangladesh Economic Review. (2017, 2018). Finance Division. Ministry of Finance, Government of the people's republic of Bangladesh.

04. Bangladesh National Budget Speech 2013-14, 2019-20. Ministry of Finance.

05. BBS. (2011). Household income and expenditure survey 2010.

06. BBS. (2017). Household income and expenditure survey 2016.

07. BBS. (2017). Labor force survey 2017.

08. Becker, S. Gary. (1975) "Human Capital: A Theoretical and Empirical Analysis, with Special Reference to Education". National Bureau of Economic Research. Columbia University Press. 2nd Edition.

09. Blundell, R., Dearden, L., Meghir, C., \& Sianesi, B. (1999). "The returns from education and training to the individual, the firm and the economy", Fiscal Studies, 20(1), 1-23.

10. Central Intelligence Agency: The world factbook, Bangladesh demographic profile (2018).

11. Goldin, C. (2016) Human Capital. "Handbook of Cliometrics". Springer, Berlin, Heidelberg.pp 55-86.

12. Hossain, R. (2015). "Current status of health sector in Bangladesh". Bangladesh Medical Journal. January 44 (1). http://dx.doi.org/10.1016/S0140-6736(18)31941-X._Accessed on July 12, 2019.

13. Human Development Indices and Indicators, Bangladesh: 2018. Statistical Update. Available at: http://hdr.undp.org/sites/all/themes/hdr_theme/country-notes/BGD.pdf. Accessed on July 12, 2019.

14. Human Development Report 2017, UNDP.

15. Islam, M, R. (2014). "Education and Economic growth in Bangladesh-An Econometric Study". IOSR journal of Humanities and Social Science. 19(2). 102-110.

16. Islam, R. (2014). "Human capital and inclusive growth: The challenges for Bangladesh". In workshop on vision. Bangladesh Economist Forum. (Vol.3030).1-36.

17. Khan, A. R. (2007). Asian experience on growth, employment and poverty: An overview with special reference to the findings of some recent case studies. ILO, Geneva and UNDP, Colombo

18. Kucharcikova, A. (2014). "Investment in the human capital as the source of economic growth". Periodica Politechnica Social and Management Science. 22(1). 29-35.

19. Labor force survey. BBS. (2018). Statistical Yearbook of Bangladesh. Statistics Division, Ministry of Planning, Dhaka, Government of the People's Republic of Bangladesh.

20. Laroche, M. Merette, M. \& Ruggeri, G. C. (1999). “On the concept and dimensions of human capital in a knowledge-based economy context". Canadian Public Policy, 25(1), 87-100.

21. Lim, S. S., Updike, R. L., Kaldjian, A. S., Barber, R. M., Cowling, K., York, H., ... \& Leever, A. T. (2018). Measuring human capital: a systematic analysis of 195 countries and territories, 1990-2016. The Lancet, 392(10154), 1217-1234.

22. Nazar, R., \& Chaudhry, I. S. (2017). The return on investment for education in Pakistan. Pakistan Journal of Commerce and Social Sciences (PJCSS), 11(3), 1069-1083.

23. OECD Insights: The value of people. (2016). Population reference bureau.(2). 1-18. 
24. Psacharopoulos, G., \& Patrinos, H. A. (2018). Returns to investment in education: $a$ decennial review of the global literature. The World Bank.

25. Rahman and Al-Hasan (2018). "Return to schooling in Bangladesh revisited: An Instrumental variable quantile regression approach. Centre for policy dialogue. Munich Personal RePEc Archive no 90132.

26. Ravi, P. R. E. (2010). Bangladesh National Health Accounts 1997-2007. Health Economics Unit, Ministry of Health and Family Welfare, Government of the people's republic of Bangladesh. Available from :www.heu.gov.bd/ phoca download/ bnha\%201997-2007.pdf

27. Statistics, B. B. O. (2011). Statistical Yearbook of Bangladesh. Statistics Division, Ministry of Planning, Dhaka, Government of the People's Republic of Bangladesh.

28. The World Bank. IBRD.IDA.

29. United Nations Educational, Scientific, and Cultural Organization (UNESCO) Institute for Statistics by Index Mundini.

30. Weil, A. (2013). Basic number theory (Vol. 144). Springer Science \& Business Media.

31. Wilson, R. A., \& Briscoe, G. (2004). The impact of human capital on economic growth: a review. Impact of education and training. Third report on vocational training research in Europe: background report. Luxembourg: EUR-OP. Cedefop Reference Series, 54. 